\title{
TIPE PEMISAHAN DAN PENGARUHNYA TERHADAP LABA PADA BANK UMUM SYARIAH HASIL PEMISAHAN
}

\author{
M. Nur Rianto Al Arif, \\ Ismawati Haribowo \\ UIN Syarif Hidayatullah Jakarta - Indonesia
}

\begin{abstract}
The Islamic banking spin-off according to the Act No. 21 years 2008 can take two spin-off's type such asspinoff that using acquisition, convert, merger and spinoff; and; pure spinoff. The aim of this research is to analyze if there is a difference between the spinoff's type and profit at spinoff's bank. This research is using panel regression with random effect. The result shows there is no difference between type of spinoff and operational profit at spinoffs bank. This result implies that the spinoff type is decided according the business strategy that are going to choose by the parent's bank. There are a lot of factors that are going to be considered to choose the spinoff's type for separate the Islamic business unit from its parent's bank.
\end{abstract}

Keywords: spinoff's type; profit; panel regression; Islamic bank

\section{PENDAHULUAN}

Perkembangan industri perbankan syariah di Indonesia cukup pesat, terutama setelah lahirnya Undang-undang No. 21 tahun 2008 tentang Perbankan Syariah. Jika merujuk pada data per Desember 2014 telah terdapat 12 Bank Umum Syariah, 22 Unit Usaha Syariah, dan 163 BPRS. Apabila sebelum tahun 2008 terlihat bahwa jumlah Bank Umum Syariah hanya sebanyak 3 bank, namun setelah lahirnya Undang-undang ini mampu menambah jumlah bank umum syariah cukup signifikan.
Untuk mengembangkan industri perbankan syariah di Indonesia, Bank Indonesia telah menyusun cetak biru pengembangan industri perbankan syariah pada tahun 2002 dan edisi revisinya pada tahun 2005-2006 (Ismal, 2011). Selain itu, Bank Indonesia bekerjasama dengan seluruh pemangku kepentingan di industri perbankan syariah menyusun suatu program akselerasi pada tahun 2007-2008, dimana program ini berkonsentrasi pada pencapaian pangsa pasar sebesar 5\% pada akhir tahun 2008. Tabel 1.2. menunjukkan pada akhir tahun 2008, pencapaian pangsa pasar hanya mencapai $2.10 \%$ saja. Belum tercapainya target ini menjadikan Bank In-

Korespondensi dengan Penulis:

M. Nur Rianto Al Arif, HP +62818118746

e-mail:nur.rianto@uinjkt.ac.id 


\section{Jurnal Keuangan dan Perbankan | PERBANKAN}

Vol. 20, No.3, September 2016: 479- 486

donesia mengubah target pangsa pasar pada akhir tahun 2009 diharapkan pangsa pasar telah mencapai $3.5 \%$, dan pada akhir tahun 2010 telah mencapai 4.75\% (Ismal, 2011). Namun, sampai dengan akhir tahun 2014, target pangsa pasar sebesar 5\% pun belum tercapai, sehingga memunculkan istilah "five percent trap" di kalangan industri perbankan syariah atas belum tercapainya target tersebut.

Salah satu hal penting yang terdapat pada Undang-undang ini adalah terdapatnya pasal yang mengatur mengenai pemisahan unit usaha syariah menjadi bank umum syariah, hal ini sebagaimana yang diatur dalam Pasal 68 ayat 1 . Hal ini kemudian diperkuat dengan terbitnya Peraturan Bank Indonesia No. 11/10/PBI/2009.Terdapat dua pendekatan pemisahan unit usaha syariah yang dapat dilakukan, yaitu: pertama, menggunakan badan hukum yang sudah ada, dimana pada pendekatan ini bank umum konvensional yang telah memiliki UUS mengakuisisi bank yang relatif kecil kemudian mengkonversinya menjadi syariah kemudian memisahkannya serta menggabungkan UUS-nya dengan bank yang baru dikonversi tersebut. Bank
Umum Syariah (BUS) pendekatan pertama ialah: BRI Syariah, Bukopin Syariah, BTPN Syariah. Kedua, menggunakan badan hukum yang baru, dimana pada pendekatan kedua ini bank umum konvensional melakukan pemisahan atas UUS yang dimiliki, kemudian UUS tersebut dijadikan Bank Umum Syariah (BUS) tersendiri -hal ini dikenal sebagai pemisahan murni-, yaitu BNI Syariah dan Bank Jabar Banten Syariah. Kedua pendekatan secara umum dapat terlihat pada Tabel 2.

Pada tahun 2008 - 2014 Banyak perbankan syariah berbentuk Unit Usaha Syariah (UUS) melakukan spin off (memisahkan diri dari bank Induk) dengan membentuk Bank Umum Syariah (BUS) dengan alasan ingin memajukan perbankan syariah dan lebih independen dalam melakukan manajemen diri. Dari lima Bank Umum Syariah (BUS) hasil pemisahan, yang lahir murni melalui proses pemisahan unit usaha syariah adalah BNI Syariah dan Bank Jabar Banten Syariah, sedangkan BUS lainnya banyak muncul melalui proses akuisisi dan konversi.

Tabel 1. Jaringan Perbankan Syariah

\begin{tabular}{lccccccccc}
\hline & $\mathbf{2 0 0 6}$ & $\mathbf{2 0 0 7}$ & $\mathbf{2 0 0 8}$ & $\mathbf{2 0 0 9}$ & $\mathbf{2 0 1 0}$ & $\mathbf{2 0 1 1}$ & $\mathbf{2 0 1 2}$ & $\mathbf{2 0 1 3}$ & $\mathbf{2 0 1 4}$ \\
\cline { 2 - 9 } & & & & & & & & & \\
Perbankan Syariah & 3 & 3 & 5 & 6 & 11 & 11 & 11 & 11 & 12 \\
Bank Umum Syariah & 20 & 26 & 27 & 25 & 23 & 24 & 24 & 23 & 22 \\
Unit Usaha Syariah & 105 & 114 & 131 & 138 & 150 & 154 & 158 & 163 & 163 \\
BPRS & & & & & & & & & \\
Jumlah Kantor & 349 & 401 & 581 & 711 & 1,215 & 1,349 & 1,745 & 1,998 & 2,151 \\
Bank Umum Syariah & 183 & 196 & 241 & 287 & 262 & 300 & 517 & 590 & 320 \\
Unit Usaha Syariah & 105 & 185 & 202 & 225 & 286 & 362 & 401 & 402 & 439 \\
BPRS & & & & & & & & &
\end{tabular}

Sumber: Statistik Perbankan Syariah, Bank Indonesia

Tabel 2. Bank Hasil Pemisahan Pasca UU No. 21/2008

\begin{tabular}{clcc}
\hline No & \multicolumn{1}{c}{ Bank } & Tahun Spin-off & Bentuk \\
\hline 1 & Bank Syariah BRI & 2008 & Akuisisi dan konversi \\
2 & Bank Syariah Bukopin & 2008 & Akuisisi dan konversi \\
3 & Bank Jabar Banten Syariah & 2010 & Pemisahan murni \\
4 & BNI Syariah & 2010 & Pemisahan murni \\
5 & Bank BTPN Syariah & 2014 & Akuisisi dan konversi \\
\hline
\end{tabular}

Sumber: Statistik Perbankan Syariah, Bank Indonesia 
Jika merujuk pada kriteria pada UU No. 21 tahun 2008 pasal 68 ayat 1, sembilan BUS hasil pemisahan tersebut belum ada satupun yang memenuhi kriteria wajib pisah. Suatu UUS wajib pisah jika aset (UUS) telah mencapai 50\% aset bank induknya atau 15 tahun setelah UU No. 21 tahun 2008 diperundangkan. Oleh karenanya dapat dibilang pemisahan yang dilakukan ialah pemisahan yang prematur (premature spin-off), karena sebenarnya belum memenuhi kriteria sebagaimana yang terdapat dalam UU No. 21 tahun 2008 pasal 68 ayat 1.Al Arif (2015) menunjukkan bahwa kebijakan pemisahan justru berdampak pada menurunnya tingkat efisiensi pada industri perbankan syariah. Al Arif (2015) menunjukkan bahwa kebijakan pemisahan tidak berpengaruh terhadap jumlah pembiayaan pada bank umum syariah hasil pemisahan. Hamid (2015) menunjukkan bahwa kebijakan pemisahan yang dilakukan mampu meningkatkan profitabilitas pada bank umum syariah hasil pemisahan.

Terkait dengan pendekatan atau tipe dalam pemisahan unit usaha syariah menjadi bank umum syariah, Rizqullah (2013) dalam kajian yang dilakukan menunjukkan bahwa metode pemisahan unit usaha syariah menjadi bank umum syariah yang paling baik ialah dengan membentuk badan/ perusahaan baru atau dengan cara melakukan pemisahan murni karena tipe pemisahan ini lebih praktis dibandingkan dengan pemisahan menggunakan badan hukum yang sudah ada. Urutan alternatif pendirian berikutnya ialah pemisahan dengan menggunakan badan hukum yang sudah ada. Oleh karenanya penelitian ini memiliki tujuan untuk melakukan suatu analisis empiris apakah tipe pemisahan yang dipilih oleh bank umum syariah hasil pemisahan akan berdampak pada jumlah laba operasionalnya. Selain itu penelitian ini akan bermanfaat bagi penentuan keputusan unit usaha syariah yang akan melakukan pemisahan.

\section{METODE}

Untuk menjawab tujuan dari penelitian ini yaitu untuk menganalisis pengaruh tipe pemisahan terhadap laba bank umum syariah hasil pemisahan akan dipergunakan regresi panel. Tahapan dalam melakukan regresi panel yang dilakukan dalam penelitian ini ialah sebagai berikut (Nachrowi dan Usman, 2006):

1. Melakukan estimasi dengan menggunakan model efek tetap.

2. Melakukan uji Chow untuk memilih antara model pooled ordinary least square (PLS) dengan MET. Pengujian menggunakan uji chow didasarkan pada hipotesis

$\mathrm{H}_{0}=$ intersep konstan pada setiap $\mathrm{i}$ dan $\mathrm{t}$ $\mathrm{H}_{1}=$ intersep tidak konstan pada setiap $\mathrm{i}$ dan $\mathrm{t}$ Jika nilai F-test maupun chi-square signifikan, maka $\mathrm{H}_{0}$ ditolak sehingga model efek tetap lebih baik dibandingkan dengan model PLS.

3. Melakukan uji Hausman untuk memilih antara model efek tetap dengan model efek acak. Adapun hipotesis yang diuji ialah:

$\mathrm{H}_{0}=$ random effect (individual effect uncorelated)

$\mathrm{H}_{1}=$ fixed effect

Apabila nilai uji Hausman signifikan, maka $\mathrm{H}_{0}$ ditolak sehingga model efek tetap (fixed effect) lebih baik jika dibandingkan dengan model efek acak (random effet).

Adapun data laporan keuangan yang dipergunakan ialah data kuartal dari Kuartal II tahun 2010 sampai dengan kuartal II tahun 2015. Jumlah bank yang diobservasi ialah sebanyak empat bank umum syariah hasil pemisahan, yaitu Bank BNI syariah, Bank BRI syariah, Bank Bukopin syariah, dan Bank BJB Syariah. Alasan mengapa hanya empat bank ini saja yang dipilih, karena faktor ketersediaan data yang memadai, selain itu keempat bank ini telah cukuplama telah menjadi Unit Usaha Syariah (UUS).

Untuk mengukur pengaruh tipe pemisahan terhadap jumlah laba operasional pada bank umum syariah hasil pemisahan akan mempergunakan 


\section{Jurnal Keuangan dan Perbankan | PERBANKAN}

Vol. 20, No.3, September 2016: 479- 486

variabel dummy. Selain variabel dummy dimasukkan pula faktor internal berupa variabel dana pihak ketiga dan nilai efisiensi (rasio BOPO), serta faktor eksternal berupa tingkat inflasi, tingkat bunga bank konvensional, dan tingkat pertumbuhan ekonomi. Persamaan regresi yang diajukan pada penelitian ini untuk mengukur dampak kebijakan pemisahan terhadap jumlah laba ialah:

$$
\begin{aligned}
\text { Laba }_{\text {it }}= & \alpha+\beta_{1}{\mathrm{D} \_ \text {spinoff }_{i t}}+\beta_{2} \mathrm{DPK}_{\mathrm{it}}+\beta_{3} \mathrm{BOPO}_{\mathrm{it}}+ \\
& \beta_{4} \mathrm{Laba}_{\mathrm{it}}+\beta_{5} \text { Marjin }_{\mathrm{it}}+\beta_{6} \mathrm{NPF}_{\mathrm{it}}+\varepsilon_{\mathrm{it}}
\end{aligned}
$$

\section{Dimana:}

Laba $_{\text {it }} \quad$ : laba bankumum syariah hasil pemisahan

D_spinoff it $_{\text {: }}$ dummy bentuk spin-off

Dimana : 0 = akuisisi dan konversi;

$1=$ pemisahan murni

DPK $_{\text {it }} \quad$ : dana pihak ketiga bank umum syariah hasil pemisahan

Pemb $_{\text {it }} \quad$ : jumlah penyaluran pembiayaan bank umum syariah hasil pemisahan

$\mathrm{BOPO}_{\text {it }} \quad$ : rasio efisiensi bank umum syariah hasil pemisahan

Marjin $_{\text {it }}$ : tingkat ekuivalen marjin deposito bank umum syariah hasil pemisahan

$\mathrm{NPF}_{\mathrm{t}} \quad$ : tingkat pembiayaan bermasalah

\section{HASIL}

Dalam menganalisis hasil yang didapat pada penelitian ini, ada beberapa tahapan yang harus dilakukan. Hal yang pertama dilakukan ialah melakukan estimasi dengan menggunakan pooled least square. Kemudian dilanjutkan dengan regresi dengan model efek tetap. Setelah itu akan dilanjutkan dengan melakukan uji Chow untuk melihat apakah model yang baik apakah model PLS ataukah model efek tetap. Apabila model yang baik ialah model efek tetap, maka estimasi akan dilanjutkan dengan menggunakan efek acak, dan melakukan uji Haus- man untuk melihat apakah model yang terbaik apakah model dengan efek tetap ataukah dengan efek acak.

Tabel 3. Hasil Uji Chow

Redundant Fixed Effects Tests

Equation: HASIL_LABA

Test period fixed effects

\begin{tabular}{lrrr}
\hline \hline Effects Test & Statistic & d.f. & Prob. \\
\hline \hline Period F & 1.669180 & $(20,57)$ & 0.0674 \\
Period Chi-square & 38.724967 & 20 & 0.0072 \\
\hline
\end{tabular}

Hasil uji Chow pada Tabel 3 menunjukkan bahwa hipotesis $\mathrm{H}_{0}$, yaitu intersep konstan pada setiap i dan $t$ ditolak. Hasil uji Chow yang menolak hipotesis nol menunjukkan bahwa penggunakan regresi panel dengan model efek tetap lebih baik dibandingkan dengan model pooled least square.

Tabel 4. Hasil Uji Haussman

Correlated Random Effects - Hausman Test

Equation: HASIL_LABA

Test period random effects

\begin{tabular}{lrrr}
\hline Test Summary & Chi-Sq. Statistic & Chi-Sq. d.f. & Prob. \\
\hline \hline Period random & 3.975631 & 6 & 0.6800 \\
\hline
\end{tabular}

Kemudian hasil uji Hausman menunjukkan bahwa hipotesis $\mathrm{H}_{0}$ tidak dapat ditolak. Hasil uji Hausman yang tidak menolak hipotesis non menunjukkan dalam penelitian ini penggunaan regresi panel dengan model efek acak lebih baik daripada model efek tetap. Oleh karenanya yang terbaik dalam penelitian ini ialah regresi panel menggunakan model efek acak.

Hasil estimasi dengan menggunakan efek acak menunjukkan pula bahwa tidak ada pengaruh antara tipe pemisahan dengan jumlah laba operasional di bank umum syariah hasil pemisahan. Hal ini memperlihatkan bahwa tipe pemisahan apakah itu melalui pemisahan murni ataukah melalui akuisisi, konversi, dan merjer tidak mempengaruhi 
keputusan dalam besar kecilnya laba operasional pada bank umum syariah hasil pemisahan. Oleh karenanya setiap unit usaha syariah yang hendak melakukan pemisahan dapat memilih salah satu dari kedua tipe pemisahan ini tergantung kepada kebutuhan dari institusi bersangkutan.

\section{PEMBAHASAN}

Hasil dalam penelitian ini merupakan salah satu pembuktian empiris atas penelitian yang dilakukan oleh Rizqullah (2013), dimana menunjukkan bahwa tipe pemisahan unit usaha syariah menjadi bank umum syariah ialah dengan cara membentuk badan hukum atau perusahaan baru hal ini dinyatakan sebagai pemisahan murni dalam penelitian ini-. Namun penelitian yang dilakukan oleh Rizqullah (2013) ini rawan dengan potensi konflik kepentingan dikarenakan peneliti bersangkutan merupakan kepala pimpinan unit usaha syariah ketika BNI Syariah memutuskan untuk melakukan pemisahan dan pemisahan yang dilakukan oleh BNI Syariah ialah dengan cara pemisahan murni.

Rizqullah (2013) menyatakan bahwa dalam menentukan pilihan strategis metode pemisahan

Tabel 5. Hasil Estimasi Tipe Pemisahan dan Laba dengan Efek Acak

Dependent Variable: LABA

Method: Panel EGLS (Period random effects)

Sample: 2010Q2 2015Q2

Periods included: 21

Cross-sections included: 4

Total panel (balanced) observations: 84

\begin{tabular}{|c|c|c|c|c|}
\hline Variable & Coefficient & Std. Error & t-Statistic & Prob. \\
\hline $\mathrm{C}$ & 122478.4 & 25316.50 & 4.837887 & 0.0000 \\
\hline DPK & 0.002803 & 0.002237 & 1.252886 & 0.2140 \\
\hline PEMBIAYAAN & 0.002619 & 0.001887 & 1.387983 & 0.1691 \\
\hline D_TIPE & -1068.527 & 6055.078 & -0.176468 & 0.8604 \\
\hline MARJIN & -10272.11 & 3198.663 & -3.211377 & 0.0019 \\
\hline BOPO & -443.8346 & 122.7159 & -3.616765 & 0.0005 \\
\hline NPF & -5079.053 & 2228.469 & -2.279167 & 0.0254 \\
\hline \multicolumn{5}{|c|}{ Effects Specification } \\
\hline & & & S.D. & Rho \\
\hline Period random & & & 11312.70 & 0.1756 \\
\hline Idiosyncratic random & & & 24512.10 & 0.8244 \\
\hline \multicolumn{5}{|c|}{ Weighted Statistics } \\
\hline R-squared & \multirow{5}{*}{\multicolumn{2}{|c|}{$\begin{array}{l}\text { 0.632744 Mean dependent var } \\
\text { 0.604126 S.D. dependent var } \\
\text { 24348.51 Sum squared resid } \\
\text { 22.11047 Durbin-Watson stat } \\
0.000000\end{array}$}} & & 23003.37 \\
\hline Adjusted R-squared & & & & 38698.50 \\
\hline S.E. of regression & & & & $4.56 \mathrm{E}+10$ \\
\hline F-statistic & & & & 1.440206 \\
\hline \multirow[t]{2}{*}{ Prob(F-statistic) } & & & & \\
\hline & \multicolumn{3}{|c|}{ Unweighted Statistics } & \\
\hline R-squared & \multicolumn{3}{|c|}{0.617483 Mean dependent var } & 31304.73 \\
\hline Sum squared resid & \multicolumn{3}{|c|}{ 5.46E+10 Durbin-Watson stat } & 1.493991 \\
\hline
\end{tabular}




\section{Jurnal Keuangan dan Perbankan | PERBANKAN}

Vol. 20, No.3, September 2016: 479- 486

terdapat elemen-elemen penting yang harus mendapat perhatian, yaitu: pertama, respon masyarakat/nasabah; kedua, respon pesaing; ketiga, model bisnis yang menggambarkan rencana bisnis pasca pemisahan; keempat, program integrasi; kelima, program komunikasi; keenam, pengalihan status pegawai; ketujuh, lembaga penunjang; kedelapan, kecepatan eksekusi; kesembilan, kesesuaian regulasi; kesepuluh, pertimbangan strategis; kesebelas, pengelolaan sistem IT.Rahma D (2015) dalam penelitiannya menjelaskan bahwa berdasarkan faktor-faktor yang menjadi pertimbangan dalam pemilihan metode pemisahan, dapat disimpulkan dari 23 variabel yang digunakan dalam penelitian ini dapat dikelompokkan atau direduksi menjadi 6 kelompok/ faktor yang menjadi pertimbangan dalam proses pemisahan. Keenam faktor tersebut yaitu: pertama, faktor perencanaan strategis atau strategic planning; Kedua, kemudahan atau practicality proses pemisahan; Ketiga, kepentingan stakeholder atau stakeholders concern;Keempat, orientasi internal; Kelima, pengelolaan sistem IT atau IT drivers;Keenam,faktor infrastruktur.

Pertimbangan yang diambil ketika memilih pemisahan dengan cara membentuk badan hukum baru dipengaruhi beberapa elemen atau faktor. Ketika suatu UUS akan memutuskan untuk pemisahan dengan tipe pemisahan murni elemen yang mempengaruhi menurut Rizqullah (2013), Rahma D (2015), dan Rifin, dkk (2015) ialah: budaya perusahaan, program komunikasi, respon nasabah, delivery channel, respon pesaing, perpajakan, kepraktisan, infrastrukturdan rencana strategis. Sedangkan ketika suatu UUS akan memisahkan diri dengan tipe pemisahan kedua yaitu dengan menggunakan badan hukum yang sudah ada atau dengan cara akuisisi, konversi, dan merger maka elemen yang mempengaruhi menurut Rizqullah, (2013) dan Rahma D (2015) ialah pengalihan status pegawai, sistem pelaporan dan pembukuan, sistem IT, perpajakan, respon regulator, due diligence, stakeholders concern, dan orientasi internal.
Perbedaan elemen-elemen tersebut menunjukkan bahwa prioritas permasalahan yang terdapat pada kedua metode tersebut juga berbeda. Pemisahan unit usaha syariah menjadi bank umum syariah harus dipandang sebagai suatu aksi korporasi dan bukan sekedar melaksanakan amanat dari undang-undang. Selain pertimbangan di atas, aspek permodalan turut menjadi salah satu pertimbangan. Berdasarkan Peraturan Bank Indonesia Nomor 11/10/PBI/2009 dinyatakan bahwa modal disetor bagi UUS yang memutuskan pemisahan dengan cara menggunakan badan hukum baru/pemisahan murni ditetapkan paling kurang sebesar lima ratus milyar rupiah. Sedangkan pemisahan dengan menggunakan badan hukum yang sudah ada hanya membutuhkan modal disetor sebesar 100 milyar. Permodalan baik yang menggunakan tipe pemisahan pertama maupun kedua wajib ditingkatkan sampai dengan 1 triliun rupiah selama sepuluh tahun semenjak bank umum syariah hasil pemisahan tersebut beroperasi.

Insentif untuk dapat mendirikan bank umum syariah baru hanya dengan permodalan sebesar 100 milyar ataupun 500 milyar masih kurang tepat. Karena jika ini yang ditempuh, maka bank umum syariah tersebut hanya akan masuk dalam kategori bank BUKU 1 yang kegiatan bisnisnya terbatas, sedangkan apabila bank syariah bersangkutan masih berupa unit usaha syariah dapat memanfaatkan fasilitas dari bank induk konvensionalnya yang telah BUKU 3 ataupun BUKU 4. Pertimbangan utama yang harus menjadi dasar pemisahan unit usaha syariah menjadi bank umum syariah ialah kinerja unit usaha syariah bersangkutan. Klepper dan Thompson (2010) menyatakan bahwa perusahaan yang memiliki kinerja lebih baik akan cenderung untuk memiliki kinerja pasca pemisahan. Oleh karenanya jika bank umum konvensional menginginkan bank umum syariah hasil pemisahan akan memiliki kinerja yang lebih baik, maka kinerja pada saat unit usaha syariah pun harus memiliki kinerja yang baik. Hal ini bertujuan agar 
ketika unit usaha syariah tersebut telah menjadi bank umum syariah, maka ia akan dapat beroperasi secara mandiri dan tidak tergantung lagi kepada bank induknya. Nasuha (2013) dimana pada penelitian yang dilakukan menunjukkan bahwa pemisahan yang dilakukan hanya menunjukkan perbedaan kinerja pada aset, pembiayaan, dan dana pihak ketiga; sedangkan pada variabel CAR, FDR, ROA, dan ROE tidak menunjukkan perbedaan antara sebelum dan sesudah pemisahan. Al Arif (2015) dalam penelitiannnya menunjukkan bahwa kebijakan pemisahan yang dilakukan tidak memberikan perbedaan pada aset, dana pihak ketiga, dan pembiayaan. Selain itu diperkirakan tidak akan ada satupun unit usaha syariah mampu mencapai $50 \%$ proporsi aset dari bank induknya sebagaimana yang ditetapkan oleh Undang-undang.

\section{KESIMPULAN}

Pemisahan unit usaha syariah menjadi bank umum syariah dapat memiliki dua tipe pemisahan, yaitu: pemisahan dengan menggunakan badan hukum baru (pemisahan murni) dan pemisahan dengan menggunakan badan hukum yang sudah ada (pemisahan dengan akuisisi, konversi, dan merger). Hasil penelitian ini menunjukkan bahwa tipe pemisahan tidak berpengaruh terhadap kinerja dari bank umum syariah hasil pemisahan yang diperlihatkan oleh laba operasional yang diperoleh. Oleh karenanya pemilihan tipe pemisahan unit usaha syariah menjadi bank umum syariah harus mempertimbangkan berbagai faktor dan elemen, karena setiap tipe pemisahan yang diambil memiliki konsekuensi kelebihan dan kekurangan masingmasing. Keputusan pemisahan unit usaha syariah menjadi bank umum syariah termasuk tipe pemisahan yang akan diambil harus mempertimbangkan banyak hal. Keputusan pemisahan ini merupakan salah satu strategi bisnis yang dapat diambil dalam mengembangkan industri perbankan syariah dan bukan tujuan akhir dalam pengembangan industri perbankan syariah di Indonesia.

\section{SARAN}

Terdapat beberapa saran yang diajukan dalam artikel ini terutama terkait dengan proses pengambilan kebijakan terkait pemisahan unit usaha syariah menjadi bank umum syariah, yaitu: pertama, bank induk konvensional harus memberikan dukungan penuh kepada unit usaha syariahnya untuk memperbesar ukuran perusahaannya, sehingga siap ketika harus memisahkan diri menjadi bank umum syariah. Kedua, regulator dalam hal ini adalah otoritas jasa keuangan harus memberikan insentif khusus kepada unit usaha syariah untuk memperbesar ukuran perusahaannya. Ketiga, perlu disusun suatu strategi khusus untuk mengakselerasi pertumbuhan industri perbankan syariah di Indonesia. Keempat, unit usaha syariah harus mengembangkan ukuran perusahaannya dengan lebih memperbesar dana murah, hal ini sebagai upaya agar marjin pembiayaan yang ditawarkan kepada nasabah menjadi lebih murah sehingga kompetititf bersaing dengan bank konvensional.

\section{DAFTAR PUSTAKA}

Al Arif, M. Nur Rianto. 2015. Keterkaitan Kebijakan Pemisahan Terhadap Tingkat Efisiensi pada Industri Perbankan Syariah di Indonesia. Jurnal Keuangan dan Perbankan, Vol. 19, No. 2, Mei 2015, hlm. 295304.

Al Arif, M. Nur Rianto. 2015. The Effect of Spin Off Policy on Financing Growth in Indonesian Islamic Banking Industry. Al-Ulum, Vol. 15 (1), June 2015, pp. 173184

Al Arif, M. Nur Rianto. 2015. Evaluasi Pemisahan Unit Usaha Syariah Menjadi Bank Umum Syariah. Proceding Seminar Akademik Pembangunan Ekonomi Indonesia, 1 Desember 2015, Fakultas Ekonomi dan Bisnis Universitas Indonesia.

Hamid, Abdul. 2015. The Impact of Spin-off Policy To The Profitability on Indonesian Islamic Banking Industry. Journal Al-Iqtishad, Vol. VII (1), January 2015, pp. 131-140. 


\section{Jurnal Keuangan dan Perbankan | PERBANKAN}

Vol. 20, No.3, September 2016: 479- 486

Ismal, Rifki. 2011. The Indonesian Islamic Banking: Theory and Practices. Jakarta: Gramata Publishing

Klepper, Steven dan Peter Thompson. 2010. Disaggrements and Intra-Industry Spinoffs. International Journal of Industrial Organization, vol. 28(5), September 2010, pages 526-538

Nachrowi, D Nachrowi dan Hardius Usman. 2006. Pendekatan Populer dan Praktis Ekonometrika Untuk Analisis Ekonomi dan Keuangan. Jakarta: LPFE-Universitas Indonesia.

Nasuha, Amalia. 2012. Dampak Kebijakan Spin-off Terhadap Kinerja Bank Syariah. Jurnal Iqtishad Fakultas Syariah dan Hukum UIN Syarif Hidayatullah Jakarta, Vol. IV, No. 2Juli 2012, hlm. 241-258.

Rahma D, Hari. 2015. Pemilihan Metode Spin OffUnit Bisnis Syariah dengan Pendekatan Analisa Faktor (Studi Kasus PT BNI Syariah dan PT BRI Syariah). Tesis Tidak Dipublikasikan. Bogor: Institut Pertanian Bogor
Rifin, Amzul, dkk. 2015. Pemilihan Metode Spin Off Unit Bisnis Syariah dengan Pendekatan Analisa Faktor: Studi Kasus PT BNI Syariah dan PT Bank Syariah BRI. http://journal.ipb.ac.id/storage/journals/ 83/articles/9683/submission/review/ 9683. Diakses pada 8 Desember 2015

Rizqullah. 2013. Pemilihan Metode Spin-Off Unit Usaha Sayriah Bank Umum Konvensional Menjadi Bank Umum Syariah di Indonesia. (Disertasi Tidak Dipublikasikan). Jakarta: IEF Trisakti

Thompson, Peter dan Steven Klepper. 2005. Spinoff Entry in High-tech Industries: Motives and Consequences. Working Papers 0503, Florida International University, Department of Economics.

Tubke, Alexander. 2004. Success Factors of Corporate SpinOffs. New York: Springer.

Veld, Chris dan Yulia V Veld-Merkoulova. 2002. Do Spinoffs Really Create Value? The European Case. Research paper, Department of Finance and Center, Tilburg University, Netherlands. 